\title{
Egyptens Muslimske Broderskab i bevægelse
}

\section{Jakob Skovgaard-Petersen}

\section{Det Muslimske Broderskab i Egypten er alle}

islamistiske bevægelsers moder, og det er også i

Broderskabets hjemby, Cairo, at mange af de vigtigste islamistiske ideologer og debattører hører hjemme. Derfor er det vigtigt at følge med i, hvordan islamismen debatteres i Egypten, og hvad Broderskabet er for en størrelse

Denne artikel vil følge Broderskabets vej fra modstander til tilhænger af partipolitik, og skitsere, hvordan det agerer, og hvad det står for ideologisk i dag. Det vil basere sig det udkast til et partiprogram, som blev publiceret i august 2007.

Allerførst en definition: Islamisme er, som ordet angiver, en politisk ideologi der sigter på at indføre eller konsolidere et islamisk samfund. Islam er derimod en religion, dvs. en formulering af universets, tidens og menneskets placering og mening, knyttet til troen og dyrkelsen af en gud. Som alle andre ældre religioner har islam på den måde også i tidligere tider været garant for en samfundsorden: Muslimske teologer og jurister formulerede vejledninger og love for, hvordan man skulle leve og omgås i samfundet, for at undgå straf i efterlivet.

Men de udviklede ikke rigtigt nogen politologi; der var ikke nogen komplet formulering af indretningen af en stat, eller nogen forventning om en handlende og regulerende stat som den centrale aktør i samfundet. Der var heller ikke nogen idé om rettigheder, men alene om pligter, over for Gud og øvrigheden. Politiske ideologier kom først til Egypten og den arabiske verden med fremkomsten af moderne territoriale stater med store administrati- 
oner og borgerlige offentligheder. En af disse ideologier var islamismen, som vi dog først rigtigt ser fra 1920'erne og frem.

\section{Et nyt parti}

Den 10-14 august 2007 publicerede Egyptens nye kvalitetsavis, al-Masri al-Yaum, et længere program for et nyt politiske parti, 'De Muslimske Brødre'. Programmet indeholdt ikke de store overraskelser, idet det lå meget i forlængelse af, hvad Broderskabet havde skrevet i sit program op til valget i $2005 \mathrm{og}$ i sit manifest for reform i Egypten i 2004. Alligevel udsendte Broderskabets $\emptyset$ verste leder, generalvejleder Mehdi Akef, en erklæring om, at det ikke var det faktiske program, men kun nogle tidlige udkast.

Egentligt er hverken piratudgaven eller det ægte program - når det udkommer - helt hvad de giver sig ud for at være. For partiet eksisterer ikke, og vil ikke få lov til at eksistere. Det ved Broderskabet godt. Det vil nemlig ikke få lov til at oprette partiet formelt, hvilket vil sige, at det ikke vil kunne stille op til valg. Den kommission i parlamentet, der bestemmer, om ansøgninger om oprettelse af nye partier kan godkendes, har stort set altid sagt nej til alle. Det skyldes, at den helt er domineret af repræsentanter for regeringspartiet, det National Demokratiske Parti (NDP), som i virkeligheden blot forsvarer deres magtmonopol.
Alligevel er partikommissionen jævnligt blevet underkendt af domstolene, når de nye partier har indstæunet afslagene. Det er blot ikke sket for de tidligere partier, som folk med tilknytning til Broderskabet har ansøgt om at oprette, for her har domstolene fulgt partiloven, der fastslog, at det ikke er tilladt at oprette partier baseret på religion. Denne position er nu yderligere cementeret i den ny forfatning, som blev vedtaget i marts 2007: her forbyder paragraf fem politiske partier baseret på religion.

Et parti med navnet 'De Muslimske Brødre', og med selve Broderskabet som skaber, vil derfor med sikkerhed ikke blive legaliseret. Så intentionen med partiprogrammet er sandsynsligvis at tilnærme sig andre politiske kræfter, berolige kritikere, og at fremstå som et realistisk, og mere demokratisk, alternativ til det siddende styre.

Faktisk er Broderskabets øverste organ, eksekutivkomitéen, uenigt om, hvorvidt man overhovedet skal søge om godkendelse fra partikommissionen, eller simpelthen bare lade partiet forblive illegalt og altså ikke forsøge at stille det op. Broderskabet har selv været illegalt siden 1954, men efter Nassers død i 1970 har myndighederne i praksis tålt, at det opererede, selv om der ved hvert valg (og tit også indimellem) er bølger af arrestationer af dets medlemmer for at holde det nede.

Broderskabet forsøger i program- 
met at omgå forfatningens forbud mod religiøst baserede partier - eller måske rettere at udstille forfatningens selvmodsigelser - ved eksplicit at basere sig på dens paragraf to, der fastslår, at "Islam er statens religion, arabisk er dens officielle sprog, og principperne i den islamiske sharia er hovedkilden til lovgivningen." (Dette er den afgørende konstitutionelle forankring af islam som politisk faktor i Egypten. Paragraf to var genstand for hidsig debat i foråret 2007, da sekulariserede kræfter forsøgte at få den annulleret. Se debatten på dansk på www. dedi.org.eg under 'Hvad skriver de egyptiske aviser?')

Selv om det ikke er officielt, men formentligt en prøveballon, er partiprogrammet af vigtighed $-i$ alt fald $i$ sammenhæng med de andre politiske manifester, Broderskabet har udsendt de senere år. Først og fremmest fordi det vidner om radikale nyorienteringer i broderskabets tænkning og strategi.

\section{Fra parti-uvæsen til partidrømme}

Partier var nemlig ikke altid Broderskabets kop te. Hassan al-Banna (1906-49), der grundlagde Broderskabet i 1928 og styrede det ret egenrådigt, til han blev myrdet, var temmelig skeptisk over for sin samtids politik, ikke mindst partierne.

Det Muslimske Broderskab var i sit udgangspunkt ikke et parti, men en vækkelsesbevægelse, en reaktion på den stigende sekularisering i det egyptiske samfund. Samtidigt var det et svar på den egyptiske elites, og særligt det dominerende Wafdpartis, politiske sekularisering. Broderskabet blev i 1930'erne samlingspunkt for dem, der så landets og deres egen identitet som først og fremmest islamisk. Banna var stærkt kritisk over for den egyptiske elite, der i hans øjne 'lagde sig på maven' for europæisk kultur, selv om også den arbejdede for formel uafhængighed fra Storbritannien, som havde været den egentlige magthaver i Egypten siden 1882.

Men Banna var ligeså kritisk over for de traditionelle muslimske lærde, al-ulama, som han fandt bagstræberiske og indskrænkede. Banna og Broderskabet var en lægmandsbevægelse, der ville forme aktive, sportslige, moralske og fromme unge mænd, som i de næste generationer kunne skabe et samfund lige så ungt, dynamisk og visionært, som det muslimske samfund havde været, dengang muslimerne erobrede verden.

Som Banna selv havde mange af Broderskabets ledere fået ikke-religiøse, moderne uddannelser, og de så sig selv som modernister: Egypten skulle industrialiseres, udvikles, uddannes og i det hele forandres. Hertil behøvedes teknologi, men også organisation og mange andre ting fra Europa. Dette var der sådan set ikke noget principielt i vejen med, skrev Banna, men alt skulle vurderes 
ud fra, om det var i overensstemmelse med islam eller ej. Og først og fremmest var dette muslimernes eget valg: de muslimske samfunds uafhængighed, enhed og styrke var noget der virkelig lå Broderskabet på sinde.

Broderskabet havde ikke nogen udarbejdet forfatning eller politisk lære, og ikke noget program om magtovertagelse i Egypten. Heri adskilte det sig fra samtidige mobiliserende politiske bevægelser som kommunisterne og fascisterne, i skikkelse af partiet 'Det Unge Egypten'. Den mere umiddelbare inspiration for Broderskabet var de protestantiske missionsbevægelser, der i de år introducerede ungdomsarbejde, bønnemøder, spejderkorps og sommerlejre og mange andre nyskabelser til Egypten, som Broderskabet kopierede.

I slutningen af 1930' erne blev Broderskabet mere politisk i sine kampagner, og ved sin generalkongres i 1939 vedtog det sloganet 'Islam er religion og stat' - helt tydeligt som reaktion på nationalisternes dominerende 'Religionen er for Gud, men fædrelandet for os alle'. Samme år oprettede en fløj af broderskabet i al hemmelighed et militært korps, som i slutningen af 1940'erne forestod flere snigmord på politiske modstandere - hvilket førte til et forbud mod bevægelsen.

Det politiske system var i de år pluralistisk, med en ivrig konkurrence mellem partier, aviser og syns- punkter, samtidigt med at kongen, og ultimativt briterne, satte grænser for, hvor langt den egyptiske regering kunne gå, fx i udenrigspolitikken. Partierne var sekulariserede, og det var naturligvis en af de ting, Banna reagerede imod. Hans bevægelse var i første omgang en vækkelsesbevægelse, der skulle hjælpe egypterne til at genfinde islam og handle islamisk. Men Banna reagerede også imod partiernes snævre og selviske interessepolitik og talte nedsættende om hizbiya, partivæsen. Et parti var i hans øjne netop for partielt.

For ham var der noget højere, der skulle lede hele nationen, ummaen. Han talte gerne om samfundets behov for sammenhængskraft. Og det var islam, der skulle give denne sammenhæng og retning. Banna så samfundet som en organisme, og islam skulle være den drivende ånd. Bannas attitude var dog ikke en egentlig afvisning af parlamentarisme, og faktisk stillede han selv op til parlamentsvalgene.

\section{Antidemokratisk tendens}

Kongedømmet faldt med de Frie Officerers kup i 1952, og i 1954 tog en af dem, Gamal Abd al-Nasir (Nasser) magten. Alle politiske partier og organisationer blev forbudt, og særligt Det Muslimske Broderskab blev voldeligt undertrykt. Det led i forvejen af skismer efter Bannas $\mathrm{d} ø \mathrm{~d}$, og disse blev forstærket ved, at 
uafhængigheden som mål blev opnået, samtidigt med at undertrykkelsen først rigtigt begyndte. I fængslet udviklede særligt Sayyed Qutb (1906-66) en radikal ideologi, som naturligvis er i forlængelse af Bannas, men på afgørende punkter bryder med den.

Hvor Banna er optimist og modernist, er Qutb langt mere pessimistisk og stærkt antimodernistisk. For ham er verden af lave, og det er i grunden ikke engang noget nyt; verden består i en evig kamp mellem Guds parti og dets fjender, og igennem århundreder har Guds flok været lille bitte. Det er en illusion at tale om islamiske samfund i verden i dag. For at et samfund skal være islamisk, er det nemlig ikke nok, at indbyggerne er muslimer, som beder, faster og tager på pilgrimsfærd. Gud skal råde i alt, og intet menneskeligt må dyrkes. De få rigtige muslimer, der findes, må sande dette krav, tage bestik af situationen og så vælge den kompromisløse kamp for islam, på alle niveauer.

Sayyed Qutb havde i sit sene forfatterskab intet til overs for demokratiske institutioner, parlamenter eller fx FN. Mennesket er til for at tjene Gud, og al suverænitet tilhører ham. Folkesuverænitet er derfor kætteri, og det er menneskelig lovgivning også.

Qutbs forståelse forblev en minoritetsposition, også i den islamistiske bevægelse. Broderskabets leder efter Hassan al-Banna, Hassan al-Hudhay- bi, skrev et værk, 'Prædikanter, ikke Dommere', hvor han gik i rette med Qutb for at appropriere en anden af Guds monopoler: dommeren over menneskers gerninger. Det er ifølge Hudhaybi kun Gud, der kan dømme, om de troende er hyklere eller oprigtige, så mennesker skal ikke beflitte sig med at erklære hinanden for ikke-troende. Det store flertal af egyptere er samvittighedsfulde og troende mennesker.

Hvor Broderskabet siden 1960' erne har afsvoret vold, har Qutb inspireret en række mere militante islamistiske bevægelser i Egypten og i udlandet, inklusive Jihad-gruppen og Ayman az-Zawahiri, der i 1990' erne sluttede sig til Osama bin Laden og al-Qaeda. Broderskabet selv har heller ikke rigtigt lagt afstand Qutb, selv om det afviser den eksklusive og voldelige del af hans ideologi.

Det Muslimske Broderskab i Egypten - som har aflæggere i en række andre islamiske lande - var derfor i sit udgangspunkt ikke demokratisk, og der er også udgået en decideret anti-demokratisk ideologi fra det.

\section{Omvendelsen}

Det Muslimske Broderskab blev stærkt undertrykt i Nasser-årene fra 1954 til 1970; organisationen blev optrevlet, nogle gik i landflygtighed, mange blev fængslet og torteret og enkelte radikale som Qutb faktisk henrettet. Med Sadat skete der en 
optøning af forholdet til den politiske magt. I 1970'erne begyndte Broderskabet at lukrere på en bredere religiøs vækkelse i den egyptiske befolkning, samt finansiel støtte fra dets tilhængere og sympatisører i den nu så olierige Golf. Efter Camp David aftalerne i 1979 blev forholdet til staten igen stærkt fjendtligt. Broderskabet var nu del i en bredere islamisk bevægelse og var i en form for konkurrence med mere radikale bevægelser, som for nogles vedkommende endda var revolutionære og voldelige. Sadat blev som bekendt myrdet af en sådan bevægelse i 1981. Hans efterfølger Hosni Mubarak - som stadig er præsident - har overlevet flere attentatfors $ø g$ fra disse bevægelser.

Til de revolutionære gruppers store foragt valgte Broderskabet at deltage i den politiske proces i Egypten, selv om det ikke blev anerkendt. Men det anerkendte heller ikke fuldt det siddende styre, som i det hele taget havde problemer med at opnå folkelig legitimitet, selv om det ikke var egentligt truet.

I 1984 og 87 stillede brødrene op til parlamentsvalgene i alliance med eksisterende, legale partier, og vandt henholdsvis 15 og 17 procent at sæderne. Så der var en islamistisk blok i parlamentet, der især i begyndelsen drømte om at islamisere lovgivningen, men siden måtte slå sig til tåls med mere beskedne projekter og i det hele taget ikke fik nogen videre direkte indflydelse. Til gen- gæld mærkede man i de år tydeligt, at også regimet og NDP måtte stille sig islamisk an for at angle efter legitimitet.

1990'erne blev hårdere år for Broderskabet. Nye valglove tillod folk at stille op individuelt til Parlamentet, og der var også repræsentation af individuelle med forbindelse til Broderskabet, men de blev stadigt færre. Særligt op til valgene i 1995 satte styret ind med massiv repression, og nogle af de arresterede Broderskabskandidater og -aktivister kom til at sidde i fængsel i årevis. Broderskabet var ikke stærkt nok til en konfrontation, men valgte i stedet at koncentrere sig om græsrodsarbejde og indkassere den folkelige sympati og legitimitet, som også var produkt at undertrykkelsen.

En af grundene til den hårde kurs fra regimet var, at det var i gang med et større opgør med den militante 'Islamiske Gruppe' (al-gamaa al-islamiya), primært i det sydlige Egypten, og led store tab, både i politisoldater og økonomisk, fordi også turister blev myrdet af gruppen. Det var i de år, 1994-95, da Broderskabet bestemt ikke var på sit stærkeste, at det begyndte at udsende manifester, der skulle vise omverdenen - i og uden for Egypten - at det ikke var den trussel mod demokrati og stabilitet, som styret hævdede, men tværtimod et offer for undertrykkelse, og en garant for et mere fair og demokratisk system.

Det har ikke været let for Broder- 
skabet selv, og det synes at hænge sammen med, at en ny generation fik indflydelse på dets politik. Hvor den ældre generation havde lidt i Nassers fængsler, men på nogle punkter delte meget af nasserismens tankegods, var en yngre gruppe mindre paranoid og mere åben over for samarbejde med den øvrige opposition. Det var noget, Broderskabet havde prøvet lidt med sine koalitionspartier i parlamentet, men som den yngre gruppe især kendte til gennem politisk arbejde i faglige organisationer - såsom lægernes, advokaternes og ingeniørernes sammenslutninger - hvor Broderskabet i slutningen af 1980 'erne og i de tidlige 1990 'ere gradvist havde fået repræsentation og senere vundet kontrol.

Det var denne nye gruppe af yngre, mere pragmatiske aktivister, som nu pressede på for at få reformer. En af inspirationerne for dem var også nogle forfatterskaber, der nu formulerede nye bud på, hvordan en islamisk statsindretning, eller en islamisk social-, udenrigs-, undervisnings- eller finanspolitik kunne se ud. Men selve erfaringen med statsundertrykkelse fra Nasser og frem har sikkert også været med til at få dem til at opdage nødvendigheden af at afgræense statens magt og sikre den enkelte borgers frihed og rettigheder. I alt fald var det dette langt mere liberale vokabular, der langsomt gjorde sit indtog i Broderskabets erklæringer og litteratur.

\section{Det nye partiprogram}

Vi vender nu tilbage til det program, som Broderskabet har formuleret for sit nye parti i august 2007. Det, som det er værd at bide mærke i, er i første omgang programmets forståelse af politik.

Programmet går ud fra, at det politiske system i Egypten skal være en konstitutionel og parlamentarisk republik. Programmet betoner magtens tredeling, og domstolenes uafhængighed, men taler derudover om en fjerde statsmagt, nemlig vælgerkorpset; dette for at betone, at politikerne skal stå til ansvar, og at der skal være magtrotation.

Programmet gør en del ud af at tale om den civile stat. Dette udtryk rummer først og fremmest en afstandtagen fra teokratiet, som sunniislamistiske teoretikere altid har afvist som noget (historisk) katolsk eller shiitisk. Men det står selvfølgeligt også i modsætning til den militært baserede stat, som islamisterne typisk står overfor. I lighed med den $\varnothing$ vrige opposition forlanger programmet en ophævelse af den militære undtagelsestilstand.

Meget af dette er for så vidt ikke nyt. Islamister har igennem de senere årtier meget betonet idéen om konstitutionalisme (som de siger Muhammed opfandt), og de har fra gammel tid en forkærlighed for begrebet retsstaten, idet de ser deres samfundsmodel som lovbaseret og det modsatte af despoti (fordi også 
herskeren er underlagt loven). Med loven menes der sharia, men i programmets formulering er det intentionerne i sharia (maqasid al-Sharia), fordi de netop aldrig har været begejstrede for den klassiske islamiske jura, men derimod er på modernisternes hold, og fordi de derved vil sikre fleksibilitet og dynamik i forståelse af sharia. Kalifatet er heller ikke noget Broderskabet eller de fleste andre større islamistiske bevægelser har brugt meget krudt på gennem årene (med undtagelse af især Hizb al-Tahrir). De store sunnimuslimske bevægelser ser, med Gudrun Krämers ord, gudsstaten som en republik.

I lighed med et par andre nyere dokumenter fra Broderskabet slås det fast, at suveræniteten ligger hos borgerne i denne stat, og at disse er absolut lige og skal sikres lige muligheder, uanset $\mathrm{k} ø \mathrm{n}$, race eller religion. Som ovenfor næunt formulerede Sayyed Qutb det sådan, at suveræniteten lå hos Gud, og derved var demokratiet allerede kættersk. Dette afviser Broderskabet, og i dag formulerer det det sådan, at den suveræne Gud har delegeret sin magt til nationen (umma), som selv må forvalte sine timelige sager.

\section{Islamisk sprogbrug}

Programmet taler om at styrke demokratiet, og mange af dets visioner er også langt mere specifikt demokratiske, end man ville finde i tek- ster fra 1930'erne, 40'erne og 50' erne. Men det er også tit tåget. For det første foretrækker man at anvende ord fra den klassiske islamiske tradition, i stedet for betegnelser, der mere utvetydigt kommer fra et moderne politisk vokabular: umma (nation), shura (rådslagning), maslaha amma (almenvel) osv. Det er værd at bemærke, at alle disse ord har gennemgået omdefinitioner i det 20. århundrede, hvor de er kommet tæt på vestlige termer og institutioner, som man på den måde approprierede uden at sige det ligeud.

Men ofte er de mere upræcise og genstand for forskellige tolkninger, fra liberale til illiberale. For at komme med et eksempel: I paragraf ni siges der: "Friheden er en velsignelse fra Gud til mennesket, og derfor er den fra vort partis synspunkt en naturlig ret for enhver borger, uden diskrimination på basis af $\mathrm{k} ø$, overbevisning eller hudfarve; [baseret på princippet om at:] 'Gud har givet friheden, så den ansvarlige kan vælge mellem troen og ulydigheden over for Gud (kufr) '." Dette er for så vidt en klassisk islamisk dogmatisk position, at mennesket har en fri vilje og derfor har ansvar for sine synder. Men her står den i en moderne politisk kontekst, og hvad betyder den så?

I sin mest optimistiske læsning kan den betyde, at Broderskabet omsider giver efter for et pres, også blandt en mindre gruppe islamistiske teoretikere, og søger en ny defi- 
nition af trosfrihed, som i princippet skulle tillade at konvertere fra islam. Det er imidlertid en meget optimistisk udlægning, for det er noget Broderskabet aldrig har accepteret, og det er heller ikke udtrykt her.

Mere sandsynligt er det, at Broderskabet vil begrunde trosfrihed og tankefrihed som islamiske principper. Men muslimer har for så vidt altid accepteret, at kristne og jøder troede på noget andet. Hvorimod de muslimske lærde, og langt hovedparten af islamisterne, aldrig har accepteret religioner, der kom efter islam, som fx bahaismen. Ligger der en accept af sådanne religioner her?

Ligesådan med udtrykket 'intentionerne i den islamiske sharia'; det er elsket af liberale, fordi det giver vid handlefrihed, og bevæger lovarbejdet væk fra forpligtelse på specifikke klassiske regler og formuleringer, og hen imod bredere moralske principper. Men hvem siger, at det er sådan det skal forstås? Eller sådan det $\mathrm{i}$ praksis vil blive anvendt?

Programmet er meget lidt specifikt, når det kommer til kopterne (de egyptiske kristne) og kvindernes ligestilling. Netop her vil en absolut ligestilling klart gå imod intentionerne i den klassiske islamiske jura. Der er naturligvis sket meget på den front, siden indførelsen af forfatninger og moderne politisk tænkning, og med valgretten (som kopterne havde fra begyndelsen og kvinderne fik i 1956) er det ikke grupper, det er klogt at marginalisere for kraftigt. Så det har altid været emner, hvor Broderskabet var splittet, og hvor det er blevet kritiseret for at være reaktionært og udemokratisk.

Da Egypten tidligere på året omsider fulgte en række andre arabiske lande og tillod kvindelige dommere, var mange af Broderskabets parlamentarikere imod det. Dets progressive fløj har for nylig talt om, at det var acceptabelt med en koptisk statsminister eller præsident, hvis han blev valgt. Men en anden fløj er imod det. Valgprogrammet slår fast, at der skal være ligestilling mellem køn og religioner, og borgerrettighederne er de samme. Men det undlader at kommer med konkrete anvisninger på, hvordan denne ligestilling skal harmoneres med principperne i den islamiske sharia.

Ud over specifikke islamiske ord, benytter programmet sig også af den slags kulturelle markeringer, som også vil findes i så mange andre partiers programmer, men som godt kan ende i national chauvenisme eller ensretning. Om mange ting hedder det, at de skal foregå i overensstemmelse med den nationale kultur og identitet.

Det kan måske overraske, at Broderskabet vil bruge mange penge på kultur, kunst og medier, men det er netop for at forsvare kulturen og familien imod alt for voldsomme påvirkninger udefra. Desuden tales om et 'ikke-statsligt' råd, som skal overvåge kunsten, og sikre at den er ' $\mathrm{i}$ 
overensstemmelse med samfundets værdier, moral og traditioner.'

\section{Skepsis over for amerikanisering}

Her stikker Broderskabets traditionelle overbevisning frem om en national islamisk enhedskultur, som skal beskyttes mod vestliggørelse. Som så mange andre partier, der har til hensigt at forsvare den nationale identitet, har Broderskabet vanskeligt ved at acceptere divergerende grupper og meninger som lige så nationale og legitime. Og nye tendenser i samfundet vil stadig blive vurderet efter, om de er i overensstemmelse med islam eller ej, hvilket kan betyde manglende accept af, at fx nogle borgere er indtaget af hip-hop, heavy metal, eller andre subkulturer.

Denne skepsis over for amerikanisering mærker man naturligvis også i de udenrigspolitiske afsnit. Her understreges det, at forholdet til de vestlige magter skal baseres på gensidig respekt og jæunbyrdighed. Det taler også om at opbygge tættere forbindelser til Kina og Rusland som modvægt til den vestlige dominans (en idé der ville være helt uspiselig for Qutb og alle jihadister - for dem er de alle islams fjender som skal bekriges).

Og Egypten skal være et aktivt medlem af internationale organisationer og respektere de internationale traktater, som Egypten har underskrevet. Her sidder man og venter på, hvad programmet vil skrive om Camp David, som Broderskabet altid har været kraftigt imod. En formulering om, at trakater også kan ophæves, hvis de ikke længere forekommer rimelige for begge parter, er formodentligt en henvisning til Camp David. Men det er så forsigtigt, at det uden tvivl er udtryk for store uoverensstemmelser internt $\mathrm{i}$ Broderskabet. Det kunne man godt forestille sig blev tydeliggjort i den endelige version.

Endelig må nævnes de økonomiske visioner. Her formeligt blomstrer det med islamiske begreber. Broderskabet går ind for markeds$\varnothing$ konomi og en stærk privat sektor. Samtidigt skal staten aktivt bekæmpe monopoldannelser, åger, spil og andre økonomiske handlinger, som er forbudt ifølge islam, foruden korruption, nepotisme og den slags adfærd. Staten skal udvikle ørkenprovinserne og infrastrukturen med store projekter, følgende en femårsplan. Og den skal udvikle kernekraft til civilt brug. Turismen skal tøjles, så alle turister har sat sig ind i den nationale kultur og islams principper og kan optræde derefter.

\section{Modtagelsen}

Al-Masri al-Yaum og et par andre aviser har selv kommenteret programmet eller ladet kendte debattører gøre det. Broderskabets modstandere er (fuldt forståeligt) temmelig foragtelige over for især det økono- 
miske program. Det minder nemlig om NDP's eget (økonomisk liberalisme kombineret med store projekter i ørkenen og atomkraft), men tilsat mere økonomisk nationalisme og uanvendelige islamiske markeringer, fx den over for turisterne der i dag står får hele 12 procent af landets indtægter. Det er i kommentatorernes øjne at spille hazard med landets økonomiske velbefindende.

Broderskabet var i 1940'erne meget tæt på - og tydeligt inspireret af socialismen, idet det krævede en stærk statsstyring af økonomien, nationaliseringer og en kraftig fordelingspolitik. Dette er tonet stærkt ned siden hen; dels blev Broderskabet frastødt af Nasser og hans socialisme og tilnærmede sig det kapitalistiske Saudi-Arabien, dels er det særligt stærkt selv i den private sektor, og dels har det vel indset, at en statsøkonomi ikke er svaret. Tilbage står der en velfærdskapitalisme ikke ulig vor egen, alle islamiserende termer til trods. Det er vanskeligt at sige, at islam er løsningen (Broderskabets slagord), når det kommer til økonomien.

Til gengæld har menneskerettighedsforkæmpere gennemgående hilst programmets mere politiske og konstitutionelle dele velkommen, om end de som her finder det noget tåget og sine steder selvmodsigende. Der er jo tydeligt tale om et udkast, men netop det er faktisk i sig selv ganske rart; normalt kommunikerer Broderskabet kun udadtil gen- nem sine talsmænd i toppen, men her får man visse indtryk af de interne uenigheder; derfor vil det være interessant at sammenligne det endelige program med udkastet. Hvis Broderskabets interne debat skulle komme mere frem, ville det i sig selv være et demokratiserende skridt.

I et Danmark, hvor offentlige debattører med stor selvsikkerhed taler om islamismens demokratiske umulighed, dens fascisme, eller dens ondskab, vil et dokument som dette program forekomme ejendommeligt. Men det er bedre at søge at kende til verden, som den er, end at holde sig til forudfattede ideologiske sandheder.

Dette er ikke skrevet for at overbevise læseren om, at islamister ikke er farlige, eller altid er gode demokrater. Det ville være umuligt. Ikke blot er den islamistiske terrorisme måske vor tids største politiske problem; islamistiske regimer som Iran, Pakistan under Zia ul-Haqq og Sudan hører til blandt de groveste overtrædere af menneskerettighederne, ofte nok med påkaldelse af islam, og ikke sjældent rummer de også totalitære træk i den måde de bekæmper anderledes troende og tænkende. Vi kan alle blive enige om, at islamismen meget nemt kan forekomme i ikkedemokratiske eller (som hos Qutb) ideologisk antidemokratiske former.

Historisk kan vi dog konstatere, at også andre ideologier, fx nationalisme og socialisme, har produceret så- 
danne ikke-demokratiske regimer eller voldelige grupper. I Mellemøsten har vi også på lokalt plan mange eksempler på, at de islamistiske organisationer faktisk optræder demokratisk. Her tænker jeg ikke bare på Tyrkiet, men også på lande som Marokko og Jordan, hvor de har lov at organisere partier. Og selv har jeg fulgt Broderskabets optræden i de faglige sammenslutninger i Egypten, hvor de også overholdt de demokratiske spilleregler. Faktisk er der i mange mellemøstlige lande større demokratiske problemer med en række af de andre politiske aktører, inklusive regimerne selv.

\section{Et snæversynet samfund}

Problemet er i mine øjne ikke, at islamistiske partier skulle være særligt udemokratiske - eller at man kan finde citater af Banna der hylder den stærke stat. (For et udvalg af Bannas og Qutbs tekster på dansk, se Skovgaard-Petersen (2007). Et større udvalg af Bannas skrifter er oversat til engelsk af Wendell (1978). En grundig gennemgang af Broderskabets tidlige historie leveres af Lia (1997). Det kan man med så mange politiske bevægelser på både højre og venstrefløjen, ikke mindst i 1930'erne, og selv i Danmark.

Man kan desuden også finde udtalelser af Banna, der er stærkt kritiske over for fascismen. Først og fremmest er det imidlertid ahisto- risk og naivt at finde 60 år gamle citater og basere sine vurderinger på dem. Som vi har set, har Broderskabet foretaget store kursskifter i centrale politiske spørgsmål, som statens økonomiske og politiske rolle, eller legitimiteten af politiske partier. Det har at gøre med de rammer, bevægelserne i de enkelte lande har været underlagt, foruden generelle udviklinger i politisk og økonomisk tænkning, som med tiden også influerer islamister (eksempelvis $g \varnothing r$ programmet en del ud af miljøet, noget ingen havde drømt om for 50 år siden).

En række islamistiske bevægelser er med tiden blevet mere pragmatiske og demokratiske, fordi de erkendte, at de bedre kunne nå deres mål - eller dele af deres mål - ad den vej. Det er der ikke noget galt med, sådan er de fleste begyndt. Igen kan man ikke være sikker på, at de ville optræde komplet demokratisk, hvis de kom til magten.

Men denne indvending kunne ligeså vel rettes imod deres politiske rivaler, og den synes svag som begrundelse for præventive antidemokratiske indgreb, sådan som det skete i Algeriet. At opnå magten ad demokratisk vej ville jo desuden alt andet lige betyde, at de islamistiske bevægelser ville kunne få mange af deres ting igennem på en langtidsholdbar måde, fordi de ville have borgernes støtte.

At skabe et parti er det seneste af en række skridt, som Det Muslimske 
Broderskab har taget mod en indplacering i demokratisk konstitutionalisme. Partiet er et brud med Bannas holdning og med bevægelsens politiske tradition. Broderskabets kritikere har netop i årevis forlangt, at det stiftede et parti med et klart program, som det ville forfølge inden for konstitutionelle demokratiske rammer; netop fordi Broderskabet som religiøs organisation i lighed med andre vækkelsesbevægelser mener sig i besiddele af sandheden, var der brug for at det stiftede et parti, der bedre kunne formulere konkret politik, agere taktisk og indgå kompromiser. Når netop en ideologisk bevægelse som Broderskabet er nået frem til at kunne argumentere for og forsvare en række demokratiske institutioner og praksisser på islamisk grund, så er det opmuntrende og skal ikke affærdiges.

Problemet er derimod, at Broderskabets vision om et samfund stadig er snæversynet - og at det er godt på vej til at realisere det. Der går en konservativ religiøs vækkelse hen over Egypten, og den har efterhånden stået på i tre årtier. I medier, skoler, domstole og andre steder ser man en drejning imod det islamiske samfund, Broderskabet altid har ønsket sig, men gennem mange små skridt, og på trods af staten, ikke ved hjælp af den.

Disse skridt fører hyppigt til en stramning af, hvad man må skrive, opføre, udsige, udleve mv.; kendte liberale bliver sagsøgt og får bøder, selvcensuren breder sig, og masser af mennesker synes kun at gå op i leve rigtigt efter de islamiske (eller kristne) forskrifter. Homoseksualitet bliver undsagt, små religiøse mindretal fordømmes, piger der går for smart klædt bliver verbalt overfaldet eller det der er værre. En ny, selvretfærdig kultur breder sig, der ser sig selv som ren og god, og andre som smudsige og lavere. Denne attitude gør igen, at den enkelte unge muslim også bliver opdraget i et selvbekræftende dydsiret system, der benægter egne svagheder - og somme tider andres menneskelighed - og foretrækker at se sig selv som rene ofre for formørkede og amoralske kræfter.

Egypten har heldigvis et sprog, en humor, en folkekultur, en massekultur og en finkultur, som alle rummer rige bidrag til at forstå verden mere komplekst, mindre idealistisk og med en større erkendelse af menneskelig skrøbelighed. Men det er denne mere humanistiske kultur, som er under pres i dag.

Denne selvgodhed er sådan set også et gammelt træk i islamismen $\mathrm{i}$ Egypten, men i dag har den vind i sejlene og satser, ligesom på Bannas tid, på en islamisering fra neden, ikke fra oven.

Pointen er altså, at når partiprogrammet og det tidligere reformprogram optager så meget fra liberale forfatninger, er det fordi de har en fælles interesse i at begrænse statens magt over for borgerne. Dette 
er attraktivt for Broderskabet, fordi staten siden Nasser har været dets modstander og undertrykker, hvorimod borgerne i landet mere og mere synes at være dets allierede. I et projekt, som nok vil være politisk demokratisk, men som samtidigt vil være socialt intolerant.

\section{Efterskrift}

I september 2007, da denne artikel var afleveret, udkom så det endelige partiprogram. Set med demokratiske øjne blev det et stort tilbageskridt. Pludseligt var det holdt i et religiøst sprog, som var uklart og tvetydigt. Det ville hverken have kvinder eller koptere til at lede staten. Og værst af alt: det talte nu om at indføre et 'Råd af de øverste lærde' (hay'at kibar al- 'ulama), som skulle godkende alle præsidentielle beslutninger og parlamentariske vedtagelser. Dette var i direkte modstrid med partiets definition af sit mål som en civil stat.

Reaktionerne blandt de egyptiske politiske kommentatorer var hård. Den gennemgående kommentar var, at dette var dybt skuffende, og at Egypten nu stod med både et styre og en opposition, som hævdede, at de var demokratiske, men som ikke var det.

En kendt forsker i islamisme, Amr Shubki, konkluderede, at der havde været et paladskup i Broderskabet, hvor 'missionærerne' havde vundet over 'politikerne'. Shubki påpegede, at et sådant råd aldrig havde været en del af Broderskabets program. En anden kendt kommentator om islamiske emner, Dia Rashwan, erklærede, at et sådant råd var udtryk for en mistillid til det egyptiske folk og en afvisning af dets suverænitet, som programmet ellers forfægtede. Han påpegede endvidere, at ingen af Broderskabets grene i de andre arabiske stater havde et sådant råd på programmet. Kommentatorerne fandt, at partiprogrammet med dette råd ville indføre iranske tilstande i Egypten.

Det er også vanskeligt at se det på nogen anden måde. Som nævnt er dette noget ganske nyt og et overraskende brud med Broderskabets politik igennem de seneste 30 år. Historisk set har Broderskabet været yderst kritisk over for de muslimske lærde, al-ulama (som det anså for ineffektive og forstenede), og det er vanskeligt at forstå, at det nu pludseligt skulle give dem absolut magt.

Broderskabet har også siden dets beslutning om politisk deltagelse i 1980'erne hyldet forfatningen og forfatningsdomstolen. Det går derfor imod såvel Broderskabets politiske traditioner som hyppige udtalelser af dets ledere, at dette råd for ulama skulle afløse forfatningsdomstolen som den endegyldige juridiske autoritet.

Hele forløbet med lanceringen af planen om partiet og særligt det kolossale sving mellem den lækkede og den endelige version af partipro- 
grammet må betyde, at der er store interne spændinger i Broderskabet, både hvad angår dets politiske rolle i Egypten i dag, og hvad angår den stat som man gerne ser som endemålet. Mens dette skrives, er et større antal brødre fængslet, og der kører et par store retssager mod brødrene, hvoraf særligt én mod nogle af Broderskabets mest prominente forretningsmænd vil kunne svække det yderligere. Der er næppe tvivl om, at det officielle partiprogram vil isolere Broderskabet og forhindre det $\mathrm{i}$ at bygge forbindelser til andre dele af den egyptiske opposition. Det vil formentligt kræve et opgør om topposterne at ændre den kurs, der nu er udstukket med partiprogrammet.

Endnu bedre ville det nok være, om Broderskabet erkendte, hvor store de interne forskelle faktisk er, og blev splittet i to eller flere fraktioner.

Jakob Skovgaard-Petersen er dr. phil. og direktør for Det Dansk-Egyptiske Dialog Institut $i$ Cairo. www.dedi.org.eg

\section{Udvalgt litteratur}

Awadi, Hisham: In Pursuit of Legitimacy. The Muslim Brothers and Mubarak, 1982 2000. London, Tauris Academic Studies, 2004.

Farschid, Olaf: Hizbiya: Die Neuorientierung der Muslimbruderschaft Egyptens in den Jahren 1984 bis 1989 . Orient 30, 1, 1989, s. 5373.

Krämer, Gudrun: Gottesstaat als Republik. Baden-Baden, Nomos, 1999.

Lia, Brynjar: The Society of the Muslim Brothers in Egypt. The Rise of an Islamic Mass Movement 1928 42. Reading: Ithaca Press 1998.

Skovgaard-Petersen, Jakob: Islamismen og den sociale retfærdighed. I Tamm, Ditlev: Retfærdighedens mange ansigter. Nyt Nordisk Forlag, 2003, s. 45-68.

Skovgaard-Petersen, Jakob: Det Muslimske Broderskab i Egypten og parlamentarisk politik. I Verden i Forandring 8, temaartikler om demokrati og Mellemøsten. Syddansk Universitetsforlag, 2005, s. 86-110.

Skovgaard-Petersen, Jakob: Moderne islam. Muslimer i Cairo. 3. udg. Gyldendal, 2007. 